\title{
The effect of age on the fibrinolytic enzyme system
}

\author{
P. J. HAMilton, AUdREy A. DAWSON, D. OGSTON, AND A. S. DOUGlas \\ From the Departments of Medicine and Pathology, University of Aberdeen
}

SYNOPSIS Components of the fibrinolytic enzyme system, FR-antigen and fibrinogen, were measured in 20 healthy volunteers aged 20-40 years and in 61 elderly subjects aged 66-96 years. Plasminogen activator levels did not significantly differ between the 20-40 and 66-75 age groups, but were higher in those over 75. Plasminogen showed no change with age except for a fall in those over 75. Fibrinogen, FR-antigen, $\alpha_{1}$-antitrypsin, and $\alpha_{2}$-macroglobulin all rose with age, but the mean fibrinogen concentration fell in the very elderly.

The fibrinolytic enzyme system is a potentially powerful biological mechanism that can be activated to digest fibrin, dissolve thrombi, and lyse fibrinous exudates. However, the relevance of the fibrinolytic enzyme system to the development of atheroma and thrombosis is uncertain in spite of circumstantial evidence to support an hypothesis that diminished fibrinolytic capacity is important in their pathogenesis (Astrup, 1959). Despite the increase in clinical atheroma and thrombosis with advancing years, fibrinolytic activity has been found to remain either unaltered (Sawyer, Fletcher, Alkjaersig, and Sherry, 1960; Fearnley, Chakrabarti, and Avis, 1963; Nilsson, 1964; Moser and Hajjar, 1966) or even to increase with age (Hume, 1961; Swan, 1963). We have examined age-dependent changes in fibrinogen and the major components of the fibrinolytic enzyme system by comparing a young, healthy population with a healthy, elderly group aged 66-96 years, living in the community.

\section{Materials and Methods}

SUBJECTS STUDIED

Ten male and 10 female healthy medical students, doctors, and technicians, aged 20-40 years, none taking drugs nor hormone preparations, made up the young group.

Twenty-nine male and 32 female elderly subjects aged 66-96 years comprised the aged group. These subjects were chosen from the records of one group practice of general practitioners. No subject had a medical record of carcinoma, diabetes, venous or arterial thrombosis, hypertension, or symptomatic arteriosclerotic disease.

Received for publication 22 January 1974.
Blood was obtained from all subjects between $9.15 \mathrm{am}$ and $10.30 \mathrm{am}$, the elderly in their own homes. All were ambulant and apparently well at the time of the study.

\section{BLOOD SAMPLING}

Thirty-five ml blood was drawn into a plastic syringe through a 19 SWG needle by careful venepuncture of an antecubital vein using minimal venous stasis. Blood was distributed into tubes as required, mixed and stored at $4{ }^{\circ} \mathrm{C}$ until separated in the laboratory, and the plasma and serum were stored at $-70^{\circ} \mathrm{C}$ for up to four months.

\section{Plasma fibrinogen}

This was assessed in terms of thrombin clottable fibrinogen using a modification (Ogston and Ogston, 1966) of the method described by Ratnoff and Menzie (1951).

\section{Plasma plasminogen}

Plasma plasminogen was assayed by the caseinolytic method of Remmert and Cohen (1949) as modified by Alkjaersig, Fletcher, and Sherry (1959).

\section{Plasminogen activator activity}

This was measured by determining euglobulin clot $\omega$ lysis times (Nilsson and Olow, 1962) using citrated ${ }^{\circ}$ blood that reached the laboratory for processing 0 within 25 minutes of collection after immediate $\overparen{\varnothing}$ chilling in iced water. The results were expressed in $\stackrel{\mathscr{C}}{+}$ arbitrary units read from a $\log / \log$ linear plot of $\underline{T}$ lysis times against arbitrary units, assuming 10 such units equal a lysis time of 50 minutes and 1 unit equals 500 minutes (Sherry, Lindemeyer, Fletcher, and Alkjaersig, 1959). 


\section{Fibrinogen-related antigen}

Fibrinogen-related antigen (FR-antigen) was assayed by the method of Merskey, Kleiner, and Johnson (1966) using the modifications described by Bonnar, Davidson, Pidgeon, McNicol, and Douglas (1969). The assay was performed on serum stored at $-70^{\circ} \mathrm{C}$ prepared from $5 \mathrm{ml}$ of blood taken into plastic tubes containing $0.1 \mathrm{ml}$ of a 1:20 dilution of Aprotinin, 100000 Kallikrein Inactivator Units per $10 \mathrm{ml}$ (Trasylol, Bayer Pharmaceuticals Ltd, Haywards Heath, UK) and incubated for at least three hours at $37^{\circ} \mathrm{C}$ in a water bath before the serum was separated.

\section{$\alpha_{1}$-Antitrypsin and $\alpha_{2}$-Macroglobulin}

These were assayed by quantitative single radial immunodiffusion of serum (Mancini, Carbonara, and Heremans, 1965) using commercially prepared plates and standardized reference sera (Behringwerke A.G. Marburg/Lahn, West Germany).

\section{Erythrocyte sedimentation rate}

The erythrocyte sedimentation rate (ESR) was measured by the Westergren method (International Committee, 1973).

\section{SKINFOLD THICKNESS}

Using skin calipers (John Bull, British Indicators Ltd, St Albans, UK), subcutaneous tissue thickness was measured by one observer over the right triceps and skinfold measurements in $\mathrm{mm}$ were converted to units by the transformation $100 \log _{10}$ (reading in $0.1 \mathrm{~mm}-18$ ) as recommended by Edwards, Hammond, Healy, Tanner, and Whitehouse (1955).

\section{Statistics}

Means, standard deviations (SD), correlation coefficients ( $r$ ), and tests of significance of difference between means by Student's $t$ test and of $r$ have been calculated by standard arithmetical techniques and their probability (P) assessed from relevant tables.

In order to meet the criteria for the appropriate statistical tests, units of plasminogen activator activity and measures of FR-antigen have been logarithmically transformed to ensure their "nearnormal' distribution.

\section{Results}

An overall view of the interrelationships between fibrinogen and different constituent components of the fibrinolytic enzyme system as measured in this study, their association with each other and with sex, age, and obesity as assessed by skinfold thickness, is effected by the correlation matrix of table I. The ESR as a possible non-specific indicator of disease has also been included.

THE INFLUENCE OF AGE

In analysing changes with age the subjects were divided into four subgroups, aged 20-40 years, 66-75 years, $76-85$ years, and 86 or more years. Because there was no statistically significant association between sex and age, nor with sex and any of the various indices of fibrinolytic activity or fibrinogen, the sexes have not been distinguished in table II which details the mean and SD of each index measured for each age subgroup.

Fibrinogen showed a progressive rise in mean

\begin{tabular}{|c|c|c|c|c|c|c|c|c|c|c|}
\hline & Age & $\operatorname{Sex}$ & $\begin{array}{l}\text { Skinfold } \\
\text { Thickness }\end{array}$ & $E S R$ & Fibrinogen & Plasminogen & $E L T$ & FR-antigen & $\begin{array}{l}a_{1-} \\
\text { anti- } \\
\text { trypsin }\end{array}$ & $\begin{array}{l}a_{2^{-}} \\
\text {macro- } \\
\text { globulin }\end{array}$ \\
\hline Age & - & 0.08 & -0.08 & $\begin{array}{c}0.48 \\
P<0.001\end{array}$ & $\begin{array}{c}0.60 \\
P<0.001\end{array}$ & $0 \cdot 12$ & $0 \cdot 17$ & $\begin{aligned} & 0.58 \\
& \mathbf{P}<0.001\end{aligned}$ & $\begin{array}{r}0.34 \\
P<0.01\end{array}$ & $\begin{array}{r}0.45 \\
P<0.001\end{array}$ \\
\hline Sex ${ }^{1}$ & 0.08 & 一 & $\begin{aligned} & 0.62 \\
P< & 0.001\end{aligned}$ & 0.14 & $0 \cdot 10$ & -0.01 & 0.06 & 0.06 & 0.04 & 0.12 \\
\hline Skinfold thickness & -0.08 & $\begin{array}{c}0.62 \\
P<0.001\end{array}$ & - & 0.03 & $\begin{array}{r}0.24 \\
P<0.05\end{array}$ & 0.02 & $-0 \cdot 12$ & -0.01 & -0.09 & 0.04 \\
\hline ESR & $\begin{aligned} & 0.48 \\
P< & 0.001\end{aligned}$ & $0 \cdot 14$ & 0.03 & - & $\begin{aligned} & 0.66 \\
& \mathbf{P}<0.001\end{aligned}$ & -0.03 & 0.15 & $\begin{aligned} & 0.45 \\
& \mathbf{P}<0.001\end{aligned}$ & $\begin{array}{r}0.33 \\
P<0.01\end{array}$ & 0.09 \\
\hline Fibrinogen & $\begin{aligned} & 0.60 \\
P< & 0.001\end{aligned}$ & 0.10 & $\begin{array}{r}0.24 \\
P<0.05\end{array}$ & $\begin{array}{c}0.66 \\
\mathbf{P}<0.001\end{array}$ & - & $0 \cdot 12$ & 0.06 & $\begin{array}{r}0.33 \\
P<0.01\end{array}$ & $\begin{array}{r}0.29 \\
P<0.01\end{array}$ & 0.13 \\
\hline Plasminogen & 0.12 & -0.01 & 0.02 & -0.03 & $0 \cdot 12$ & - & $-0 \cdot 10$ & -0.12 & -0.09 & -0.03 \\
\hline ELT & 0.17 & 0.06 & $-0 \cdot 12$ & $0 \cdot 15$ & 0.06 & $-0 \cdot 10$ & 一 & $\begin{array}{r}0.29 \\
P<0.02\end{array}$ & 0.08 & 0.14 \\
\hline FR-antigen & $\begin{aligned} & 0.58 \\
P< & 0.001\end{aligned}$ & 0.06 & -0.01 & $\begin{array}{c}0.45 \\
P<0.001\end{array}$ & $\begin{array}{r}0.33 \\
P<0.01\end{array}$ & $-0 \cdot 12$ & $\begin{array}{r}0.29 \\
P<0.02\end{array}$ & - & $0 \cdot 14$ & $\begin{array}{r}0.23 \\
P<0.05\end{array}$ \\
\hline$a_{1}$-antitrypsin & $\begin{array}{r}0.34 \\
P<0.01\end{array}$ & 0.04 & -0.09 & $\begin{array}{r}0.33 \\
P<0.01\end{array}$ & $\begin{array}{r}0.29 \\
P<0.01\end{array}$ & -0.09 & 0.08 & 0.14 & - & 0.02 \\
\hline$a_{2}$-macroglobulin & $\begin{array}{c}0.45 \\
P<0.001\end{array}$ & $0 \cdot 12$ & 0.04 & 0.09 & 0.13 & -0.03 & $0 \cdot 14$ & $\begin{array}{r}0.23 \\
P<0.05\end{array}$ & 0.02 & - \\
\hline
\end{tabular}

Table I A correlation matrix detailing the correlation coefficients found between the indices measured

${ }^{1}$ A positive correlation with sex denotes a feminine characteristic, a negative correlation, a masculine one. 


\begin{tabular}{|c|c|c|c|c|}
\hline \multirow[b]{2}{*}{ Index } & \multicolumn{4}{|l|}{ Age Group } \\
\hline & $20-40$ & $66-75$ & $76-85$ & $86+$ \\
\hline $\begin{array}{l}\text { Age } \\
\text { (years) } \\
\text { ESR } \\
\text { (mm/hour) } \\
\text { Fibrinogen } \\
\text { (mg/dl) } \\
\text { Plasminogen } \\
\text { (units/ml) } \\
\text { ELT } \\
\text { (log } 10 \text { units) } \\
\text { FDP } \\
\text { (log } 10 \text { mg/l) } \\
\text { a }_{1} \text {-antitrypsin } \\
\text { (mg/dl) } \\
a_{2} \text {-macroglobulin } \\
\text { (mg/dl) }\end{array}$ & $\begin{array}{l}30 \cdot 2 \pm 5 \cdot 1 \\
(n=20) \\
5 \cdot 2 \pm 2 \cdot 8 \\
(n=20) \\
272 \cdot 5 \pm 43 \cdot 6 \\
(n=20) \\
4 \cdot 02 \pm 0 \cdot 52 \\
(n=20) \\
0 \cdot 47 \pm 0 \cdot 16 \\
(n=20) \\
0 \cdot 47 \pm 0 \cdot 40 \\
(n=19) \\
236 \cdot 1 \pm 74 \cdot 0 \\
(n=20) \\
276 \pm 24 \cdot 9 \\
(n=20)\end{array}$ & $\begin{array}{l}71 \cdot 1 \pm 2 \cdot 9 \\
(n=28) \\
10 \cdot 5 \pm 7 \cdot 4 \\
(n=25) \\
386 \cdot 0 \pm 81 \cdot 6 \\
(n=28) \\
4 \cdot 03 \pm 0 \cdot 46 \\
(n=28) \\
0 \cdot 39 \pm 0 \cdot 23 \\
(n=22) \\
0 \cdot 85 \pm 0 \cdot 32 \\
(n=28) \\
262 \cdot 3 \pm 81 \cdot 4 \\
(n=28) \\
336 \cdot 5 \pm 113 \cdot 1 \\
(n=28)\end{array}$ & $\begin{array}{l}79 \cdot 4 \pm 3 \cdot 2 \\
(n=27) \\
25 \cdot 0 \pm 19 \cdot 1 \\
(n=24) \\
403 \cdot 7 \pm 69 \cdot 4 \\
(n=27) \\
4 \cdot 01 \pm 0 \cdot 43 \\
(n=27) \\
0 \cdot 60 \pm 0 \cdot 24 \\
(n=22) \\
1 \cdot 10 \pm 0 \cdot 43 \\
(n=27) \\
298.6 \pm 53 \cdot 3 \\
(n=27) \\
319 \cdot 4 \pm 71 \cdot 8 \\
(n=27)\end{array}$ & $\begin{array}{l}89.7 \pm 3.7 \\
(n=6) \\
17 \cdot 7 \pm 7.6 \\
(n=6) \\
350.0 \pm 15.8 \\
(n=6) \\
3 \cdot 50 \pm 0.65 \\
(n=6) \\
0.63 \pm 0.32 \\
(n=6) \\
1 \cdot 43 \pm 0.35 \\
(5) \\
297.8 \pm 52.8 \\
(n=6) \\
354.3 \pm 61 \cdot 1 \\
(n=6)\end{array}$ \\
\hline
\end{tabular}

Table II The mean $\pm S D$ for parameters in the different age subgroups with numbers tested $(n)$

levels with age until the 76-85-year-old subgroup is reached after which there was a fall which is not quite statistically significant $(P>0.05)$.

Plasminogen maintained a steady mean level with age until the very elderly ( $86+$ years) age subgroup was reached when there was a significant fall compared with younger age groups $(P<0.025)$.

Plasminogen activator as measuredby the euglobulin lysis time did not significantly differ in the 20-40 and 66-75-year-old subgroups: fibrinolytic activity in the over 75s was significantly higher than in the 20-40 $(P<0.05)$ and the 66-75 $(\mathrm{P}<0.01)$ subgroups.

$F R$-antigen content of serum increased steadily ( $\mathrm{r}=0.51, \mathrm{P}<0.001)$ with age but the apparently steep increase in the over 86 compared to the 76-85year-old subgroup did not attain statistical significance.

$\alpha_{1}$-Antitrypsin and $\alpha_{2}$-macroglobulin both rose, significantly with age $(r=0.34, P<0.01 ; r=0.45$, $P<0.001)$ although the actual increases were small and only the differences in mean levels of the 20-40 and 66-75-year-old groups attained statistical significance $(P<0.05, P<0.025)$. The sex difference in levels of $\alpha_{2}$-macroglobulin described previously (Ganrot and Scherstén, 1967) was not found in this study $(r=0 \cdot 12)$.

THE INFLUENCE OF OBESITY

A narrow range of skinfold thickness was found with all subjects studied, the coefficient of variation over the triceps being only $13 \%$ in males, $8 \%$ in females. There was a predictable correlation between sex and subcutaneous tissue thickness $(\mathrm{r}=0.62, \mathrm{P}<0.001)$. If males are considered alone a significant negative association between plasinogen activator and obesity was found $(r=-0.31 ; P<0.005)$. This was not found in women. In agreement with a previous study (Warlow, McNeill, Ogston, and Douglas, 1972) obesity and fibrinogen levels were found to correlate significantly $(r=0.24, P<0.01)$.

\section{Discussion}

Studies of physiological changes associated with aging pose special problems. The definition of normality is difficult and longevity itself may isolate an abnormal population with a particular physiological response to aging. Yet despite such inherent drawbacks to any study of physiological variations in the elderly, the present results do provide some insight into the effects of age upon haemostatic factors.

We have found no significant difference in fibrinolytic activity, as assessed by the euglobulin clot lysis time, between those aged 20 to 40 and those in the 66-75 years age group. This is in keeping with most previous studies concluding that fibrinolytic activity is unrelated to age (Sawyer et al, 1960; Fearnley et al, 1963; Nilsson, 1963; Moser and Hajjar, 1966). The cause of the increased activity in subjects over the age of 75 is obscure. Exogenous factors such as anxiety, known to increase fibrinolytic activity (Ogston, McDonald, and Fullerton, 1962), are likely to be of greater importance than any age-related augmentation of the response secondary to venous occlusion (Robertson, Pandolfi, and Nilsson, 1972) for the period of venous stasis involved in obtaining blood in this study was short.

The level of both $\alpha_{1}$-antitrypsin and $\alpha_{2}$-macroglobulin, the principal antiplasmins of blood, increased with age. The $\alpha_{1}$-antitrypsin concentration is known to rise in acute and chronic inflammatory conditions, in neoplasia (Fagerhol and Laurell, 1970), and after trauma; its rise in old age may reflect cellular damage. The significance and explanation of the increase in $\alpha_{2}$-macroglobulin found 
with age is unknown: such an increase was not observed in a previous study of subjects under the age of 65 years (Ganrot and Scherstén, 1967).

The previously described rise in the plasma fibrinogen concentration with age (Ogston and Ogston, 1966) has been confirmed in this study, but the rise does not appear to progress into extreme old age: there is suggestive evidence that those over the age of 85 have a lowered fibrinogen concentration. It may be argued that such individuals are preselected because of their longevity with high fibrinogen levels militating against survival into very old age. Since the fibrinogen level is the strongest determinant of the ESR it is not surprising that this test, a frequently used non-specific indicator of disease, follows a similar pattern to the fibrinogen concentration.

This study has demonstrated a progressive and considerable increase in the level of FR-antigen with age. The significance of such a rise is uncertain. It is possible that the increased levels in old age merely represent diffuse cellular damage (Wood, Prentice, and $\mathrm{McNicol}, 1972$ ). Alternatively, in association with the reduced plasminogen levels and lack of further increase in the fibrinogen level in the very elderly, the FR-antigen increase might be interpreted as evidence of mild disseminated intravascular coagulation. The latter explanation, however, fails to take account of increased levels of FR-antigen at ages when either plasminogen remained unchanged or fibrinogen concentrations are actually raised.

A number of studies have demonstrated an association between decreased plasma fibrinolytic activity and obesity (Goldrick, 1961; Ogston and McAndrew, 1964). In the present study this association was found only in men: it seems probable that the narrow range of skinfold thickness used to assess the degree of obesity obscured the relationship in women.

It is clear that there are changes in the components of the fibrinolytic enzyme system in the elderly. How far these reflect occult tissue damage in old age or represent true physiological change must remain speculative, but they do demonstrate that any study of this system must take age into account.

We would like to thank those who volunteered to participate in this study. We are particularly grateful to Dr A. R. Robertson and his partners of Kincorth, Aberdeen, for their generous help and cooperation and their permission to approach and study some of their patients.

\section{References}

Alkjaersig, N., Fletcher, A. P., and Sherry, S. (1969). The mechanism of clot dissolution by plasmin. J. clin. Invest., 38, 1086-1095.
Astrup, T. (1959). Role of blood coagulation and fibrinolysis in the pathogenesis of arteriosclerosis. In Connective Tissue, Thrombosis and Atherosclerosis, edited by I. H. Page, pp. 223-240. Academic Press, New York.

Bonnar, J., Davidson, J. F., Pidgeon, C. F., McNicol, G. P., and Douglas, A. S. (1969). Fibrin degradation products in normal and abnormal pregnancy and parturition. Brit. med. J., 3, 137-140.

Edwards, D. A. W., Hammond, W. H., Healy, M. J. R., Tanner, J. M., and Whitehouse, R. H. (1959). Design and accuracy of calipers for measuring subcutaneous tissue thickness. Brit. J. Nutr., 9, 133-143,

Fagerhol, M. K., and Laurell, C. B. (1970). The Pi system-inherited variants of serum $\alpha_{1}$-antitrypsin. Progr. med. Genet., 7, 96-111.

Fearnley, G. R., Chakrabarti, R., and Avis, P. R. D. (1963). Blood fibrinolytic activity in diabetes mellitus and its bearing on ischaemic heart disease and obesity. Brit. med. J., 1, 921-923.

Ganrot, P. O., and Scherstén, B. (1967). Serum $\alpha_{2}$-macroglobulin concentration and its variation with age and sex. Clin. chim. Acta, 15, 113-120.

Goldrick, R. B. (1961). Fibrinolysis, blood clotting, serum lipids and body build in natives of New Guinea and Australians. Aust. Ann. Med., 10, 20-28.

Hume, R. (1961). The relationship to age and cerebral vascular accidents of fibrin and fibrinolytic activity. J. clin. Path., 14, 167-171.

International Committee for Standardization in Haematology (1973). Reference method for the erythrocyte sedimentation rate (ESR) test on human blood. J. clin. Path., 26, 301-302.

Mancini, G., Carbonara, A. O., and Heremans, J. F. (1965). Immunochemical quantitation of antigens by single radial immunodiffusion. Immunochemistry, 2, 235-254.

Merskey, C., Kleiner, G. J., and Johnson, A. J. (1966). Quantitative estimation of split products of fibrinogen in human serum, relation to diagnosis and treatment. Blood, 28, 1-18.

Moser, K. M., and Hajjar, G. C. (1966). Age and disease-related alterations in fibrinogen-euglobulin (fibrinolytic) behavior. Amer. J. med. Sci., 251, 536-544.

Nilsson, I. M. (1964). Blood coagulation studies in the aged. In Age with a Future. Proceedings of the VIth International Congress of Gerontology, edited by P. F. Hansen, pp. 629-639. Munksgaard, Copenhagen.

Nilsson, I. M., and Olow, B. (1962). Fibrinolysis induced by streptokinase in man. Acta chir. scand., 123, 247-266.

Ogston, C. M., and Ogston, D. (1966). Plasma fibrinogen and plasminogen levels in health and in ischaemic heart disease. J. clin. Path., 19, 352-356.

Ogston, D., and McAndrew, G. M. (1964). Fibrinolysis in obesity. Lancet, 2, 1205-1207.

Ogston, D., McDonald, G. A., and Fullerton, H. W. (1962). The influence of anxiety in tests of blood coagulability and fibrinolytic activity. Lancet, 2, 521-523.

Ratnoff, O. D., and Menzie, C. (1951). A new method for the determination of fibrinogen in small samples of plasma. J. Lab. clin. Med., 37, 316-320.

Remmert, L. F., and Cohen, P. P. (1949). Partial purification and properties of a proteolyticenzyme of human serum.J.biol.Chem., 181, 431-448.

Robertson, B. R., Pandolf, M., and Nilsson, I. M. (1972). 'Fibrinolytic capacity' in healthy vol'unteers at different ages as studied by standardised venous occlusion of arms and legs. Acta med. scand., 191, 199-202.

Sawyer, W. D., Fletcher, A. P., Alkjaersig, N., and Sherry, S. (1960). Studies on the thrombolytic activity of human plasma. J. clin. Invest., 39, 426-434.

Sherry, S., Lindemeyer, R. I., Fletcher, A. P., and Alkjaersig, N. (1959). Studies on enhanced fibrinolytic activity in men. J. clin. Invest., 38, 810-822.

Swan, H. T. (1963). Fibrinolysis related to age in man. Brit. J. Haemat., 9, 311-318.

Warlow, C. P., McNeill, A., Ogston, D., and Douglas, A. S. (1972). Platelet adhesiveness, coagulation, and fibrinolytic activity in obesity. J. clin. Path., 25, 484-486.

Wood, E. H., Prentice, C. R. M., and McNicol, G. P. (1972). Association of fibrinogen-fibrin-related antigen (FR-antigen) with post-operative deep-vein thrombosis and systemic complications. Lancet, 1, 166-169. 